\title{
PRAKTIK KHURUJ DALAM JAMAAH TABLIGH PERSPEKTIF MAQASID AL-SYARI‘AH
}

\author{
Nilhakim \\ Institut Agama Islam Sultan Muhammad Syafiuddin Sambas \\ Email: nilhakim30@gmail.com
}

\begin{abstract}
ABSTRACK
Khuruj is one of the teachings in Jama'ah Tabligh which requires each member to go outside the area to broadcast amr al-ma'ruf nahy al-munkar within a certain time. They go out for 3 days a month, 40 days a year, and 4 months in a lifetime. The main problem is when the obligation khuruj faced with obligations in the family. Such obligations can cause problems when members of Jama'ah Tabligh can't balance the obligation to the family in performing khuruj. On the other hand, it is very unfortunate that the lack of coordination and evaluation of care among families of members of the congregation so as to cause negative effects from the community that the tabligh worshipers less attention to families left behind. Therefore, this khuruj program should be studied with the approach of usul al-fiqh (maqasid al-syari'ah), how is khuruj allowed according to syara '. The method used in the study of the analysis conducted by looking at the benefits and harm. Based on this study, it is concluded that khuruj is a real step in the spread of Islamic syiar that not all Islamic organizations are able to implement it. However, the problem of abandoned family requires good coordination in the family, so if the members of Jamaah Tabligh do khuruj must be with the preparation of checking (family must be examined readiness related to intention, stock, physical and family to be left behind) become main and obligatory before doing khuruj so Harm can be rejected.
\end{abstract}

Keywords: Khuruj, Jamaah Tabligh, maqasid al-syari‘ah.

ABSTRAK
Khuruj merupakan salah satu ajaran dalam Jama`ah Tabligh yang
mewajibkan setiap anggotanya untuk pergi ke luar daerah untuk
menyiarkan amr al-ma'ruf nahy al-munkar dalam waktu tertentu. Yakni
keluar selama 3 hari dalam sebulan, 40 hari dalam setahun, dan 4 bulan
sekali dalam seumur hidup. Problem utama adalah saat kewajiban khuruj
dihadapkan dengan kewajiban dalam keluarga. Kewajiban tersebut dapat
menimbulkan masalah saat anggota Jamaah Tabligh tidak dapat
menyeimbangkan kewajiban untuk keluarga dalam melaksanakan khuruj.
Di sisi lain, sangat disayangkan sekali kurangnya koordinasi dan evaluasi
kepedulian antar keluarga anggota jamaah sehingga menimbulkan efek
negatif dari masyarakat bahwa jamaah tabligh kurang memperhatikan
keluarga yang ditinggalkan. Oleh sebab itu, program khuruj ini harus dikaji
dengan pendekatan usul al-fiqh (maqasid al-syari'ah), bagaimanakah khuruj
yang diperbolehkan menurut syara'. Adapun metode yang digunakan dalam
kajian berupa analisis yang dilakukan dengan melihat kemanfaatan dan
kemudaratan. Berdasarkan kajian ini, disimpulkan bahwa khuruj


merupakan langkah nyata penyebaran syiar Islam yang tidak semua organisasi Islam mampu melaksanakannya. Namun problem keluarga yang ditinggalkan diperlukan koordinasi yang baik dalam keluarga, sehingga jika anggota Jamaah Tabligh melakukan khuruj haruslah dengan persiapan pengecekkan (keluarga harus diteliti kesiapannya yang berhubungan dengan niat, bekal, fisik dan keluarga yang akan ditinggal) menjadi utama dan wajib sebelum melakukan khuruj sehingga mudarat dapat ditolak.

Kata Kunci: Khuruj, Jamaah Tabligh, maqasid al-syariah.

\section{PENDAHULUAN}

Khuruj adalah salah satu aktifitas yang sangat menonjol dalam gerakan Jama'ah Tabligh yakni suatu ajaran penting mengenai dakwah dan tabligh. Bagi Jama'ah Tabligh, pergi ke luar dalam rangka kegiatan dakwah dikenal dengan "khuruj", atau "khuruj fisabilillah (secara literal berarti keluar di jalan Allah)" (Didi Junaedi, 2013). Dengan keluar selama 3 hari dalam sebulan, 40 hari dalam setahun dan 4 bulan seumur hidup maka seseorang akan diakui sebagai anggota resmi. Dengan khuruj, anggota jama'ah dinilai dapat meneguhkan diri untuk dapat bergabung dengan perjuangan jama`ah.

Salah satu ajaran di Jama`ah Tabligh adalah mewajibkan kepada setiap anggotanya untuk melakukan khuruj tanpa melihat situasi dan kesiapan keluarga sehingga menyebabkan ada beberapa anggota yang tidak dapat menyelaraskan tanggung jawabnya sebagai kepala keluarga dengan kegiatan dakwah. Khuruj merupakan karakter yang membedakan organisasi ini dengan organisasi lainnya, yakni berdakwah keluar dari tempat ia tinggal melakukan perjalanan dakwah dari satu tempat ke tempat lainnya (Asep Muhyiddin, 2014).

Praktik Khuruj dalam ajaran Jama`ah Tabligh menggunakan landasan dalil di dalam Alquran yaitu kalimat 'ukhrijat' sebagaimana disebutkan di dalam Surah Ali Imran ayat 110. Kata 'ukhrijat' diartikan sebagai keluar dari rumah dengan melakukan perjalanan untuk berdakwah. Dalil ini menjadi landasan dakwah Jamaah ini berdasarkan mimpi yang dialami oleh pencetus gerakan ini yang bernama Muhammad Ilyas Zakariya alKandahlawi. Menurtnya, tafsir dari ayat tersebut adalah "Keluar dari rumah dan melakukan perjalanan (Muhammad Ilyas Zakariya alKandahlawi, 2000). Sedangkan menurut Quraish Shihab, kata 'ukhrijat' yang secara lafal mengandung makna keluar ditafsirkan menjadi 'diwujudkan' atau 'ditampakkan'. Kalimat tersebut. jika disambung dengan kata sebelumnya, yakni kata 'ummat', maka mengandung tafsir ummat yang diwujudkan atau ditampakkan di dunia ini sebagai umat terbaik (Shihab, 2005).

Meskipun ajaran khuruj dalam Jama'ah Tabligh tidak mempunyai kehujahan yang kuat, baik dari Alquran maupun sunnah, khuruj telah 
menjadi dogma di kalangan Jama ah Tabligh. Oleh karena itu, tulisan ini bermaksud melihat kemaslahatan dan kemudharatan dalam praktik khuruj melalui pendekatan maqasid al-syari 'ah. Maka masalah yang hendak dikaji adalah bagaimanakah khuruj yang dibolehkan yang memenuhi maksud syara'?.

\section{METODE PENELITIAN}

Penelitian ini termasuk ke dalam jenis penelitian kepustakaan (library research) dengan pendekatan kualitatif (Sugiyono, 2012). Oleh sebab itu, kajian yang dilakukan adalah kajian dokumen. Maksud kajian dokumen yakni kajian dengan literatur kepustakaan seperti peraturan perundangundangan, buku, jurnal, internet, koran, majalah dan lain-lain. Data yang digunakan merupakan data sekunder. Untuk pengumpulan datanya, peneliti melakukan telaah kepustakaan yang relevan dan dikumpulkan. Data yang terkumpul, peneliti lakukan analisis dengan pendekatan deskriptif analitis. Adapun penelitian ini menggunakan pendekatan penelitian hukum Islam doktrinal.

\section{PEMBAHASAN}

A. Prinsip Khuruj dalam Jamaah Tabligh

Khuruj merupakan aktifitas rutin yang harus dilakukan oleh aktivis dakwah dalam komunitas jamaah ini. Ia harus rajin keluar rumah untuk mengajak orang lain pada kebajikan dan mengingatkan orang lain dari azab Tuhan. Aktivis dakwah, dikenal dengan istilah karkun, harus meluangkan waktu secara maksimal dan sebaik-baiknya untuk kepentingan dakwah. Khuruj di sini bukan sekedar keluar, akan tetapi khuruj fi sabilillah. Oleh karena itu komunitas ini seringkali terlihat berkeliling dari rumah ke rumah, dari satu kampung ke kampung yang lain, dari satu daerah ke daerah lainnya bahkan dari satu negara ke negara lainnya. Ketika mereka sedang khuruj bahkan tidak boleh diganggu oleh urusan keluarga dan urusan keduniaan lainnya. Bahkan untuk kepentingan keluarga yang darurat sekalipun seperti ketika isterinya mau melahirkan, aktifis Jamaah Tabligh yang sedang khuruj tidak boleh diganggu. Untuk urusan keluarga seperti mengirim uang atau pesan dilakukan melalui utusan, teman atau orang yang dipercayainya (Hasanah, 2014).

Ada beberapa faktor mengapa anggota Jamaah Tabligh melakukan khuruj. Faktor-faktor itu terdiri internal dan eksternal. pendukungnya meliputi dukungan lahir dan batin. Dukungan lahir adalah tersedianya logistik untuk melakukan perjalanan keluar. Sedangkan dukungan batin adalah: (1) keyakinan terhadap janji Allah SWT, (2) dukungan dari pihak keluarga, (3) selalu menjaga amalan yang lima (takbiratul ula, tahajud, tilawah Alquran, tasbihat dzikir pagi, siang dan malam, dan tundukkan 
pandangan), (4) mengadakan wirid harian, (5) melaksanakan berbagai salat sunat terutama qiyamul lail, dan (6) melaksanakan ta'lim di rumah (Saepuloh, 2009).

\section{B. Teori Maqashid Al-Syari'ah}

Konsep maqashid al-syariah merupakan salah satu kajian penting di dalam hukum Islam yaikni suatu konsep yang menegaskan bahwa agama Islam hadir untuk mewujudkan kemaslahatan dan menghilangkan kemudharatan. Secara umum, para ahli mendeskripsikan teori maqashid al-syariah dengan bertumpu pada lima pokok kemaslahatan yaitu menjaga agama (hifzu al-din), menjaga jiwa (hifzun-nafsj), menjaga akal (hifzul aqli), menjaga keturunan (hifzu al-nasl), dan menjaga harta (hifzu al-mal). Dalam setiap tujuan dan tingkatan yang disebutkan tadi, terdapat lagi tingkatantingkatan yaitu dharuriyyat, hajjiyyat, dan tahsiniiyat (Musolli, 2018).

Adapun yang dimaksud dengan dharuriyyat adalah perkara-perkara yang mendesak dilakukan. Apabila tidak dilakukan dapat mengancam eksistensi dan keselamatan umat manusia. Sedangkan hajjiyyat adalah perkara-perkara yang sekunder, yang apabila tidak diwujjudkan akan mempersulit keadaan manusia, namun tidak sampai mengancam keselamatannya. Terakhir adalah tahsiniyyat, disebut juga perkara-perkara tersier atau tambahan. Artinya apabila tidak diwujudkan, tidak akan mempesulit manusia, apalagi mengancam eksistensinya. Sifat dari perkara tahsiniyyat adalah meringankan suatu kewajiban atau sebagai pelengkap atau penyempurna dalam menjalani kehidupan (Sirajuddin, 2016).

Al-Ghazzali dan al-Syatibi hanya menjadikan teori maqasid sebatas nilai etis yang bersifat akhlaqi (aksiologi). Menurut Fahmi Muhammad 'Alwan, al-Syatibi melakukan pergeseran ke ranah akhlak sehingga hal yang bersifat qanuni bagi usuliyyun dijadikannya bersifat akhlaqi (Fahmi Muhammad 'Alwan, 1989). Dengan demikian, kriteria daruriyyah dibatasi pada ancaman atas jiwa dan tubuh saja. Sementara Ibn 'Asyur melangkah lebih jauh dengan menjadikan maqasid sebagai instrumen penetapan hukum (epistemologi). Ia mendedikasikan teorinya untuk menjawab masalah hadithah sehingga dapat mendefinisikan daruriyyat secara lebih luas:

$$
\text { بالمصالح الضرورية: هي ألتي تكون الأمة مكمدوعها وآحدها في ضرورة إلى تحصيلها بحيث لا يستقيم النظام }
$$

Maslahat pada tataran darurat adalah sesuatu yang harus diwujudkan oleh umat, baik kelompok maupun individu. Indikatornya, tatanan kehidupan tidak akan tegak tanpanya, bahkan mengalami kerusakan.

Dari itu ia membedakan maqasid yang bersifat umum (al-maqasid al'ammah) dari maqasid yang bersifat khusus (al-maqasid al-khassah). Tujuan umum syariat yang berupa al-kulliyat al-khamsah menjadi rujukan nilai bagi setiap ketentuan syariat, termasuk masalah khusus yang tidak ada nas. Dalam hal ini, tujuan manusia yang sesuai dengan tujuan umum syariat dilihat sejalan dengan syariat sehingga dapat disebut al-maqasid al- 
syar'iyyah. Ibn 'Asyur (Muhammad al-Tahir ibn 'Asyur, 2005) menyebutnya maqasid al-syar'iyyat al-khassah yang didefinisikannya sebagai cara-cara yang dimaksudkan al-Syari dalam memastikan tujuan manusia yang bermanfaat dalam muamalah, atau untuk memelihara kemaslahatan umum manusia dalam aktivitas mereka yang khusus.

\section{Khuruj dalam Pandangan Maqasid Syariah}

1. Efek khuruj terhadap Hak dan Kewajiban Suami Istri

Suami Istri memiliki hak dan kewajiban masing-masing. Adanya hak dan kewajiban antara suami dan istri dalam rumah tangga dapat dilihat dalam Alquran Surah al-Baqarah ayat 228. Pada ayat tersebut, dideskripsikan bahwa seorang istri memiliki hak dan kewajiban. Kewajiban istri merupakan hak suami. Hak istri sama dengan (semisal) hak suami. Meskipun demikian, suami mempunyai kedudukan setingkat lebih tinggi, yaitu sebagai kepala keluarga sebagaimana diisyaratkan pada ujung ayat tersebut.

Masalah hak dan kewajiban suami istri dalam Undang-Undang No.1 Tahun 1974 Tentang Perkawinan diatur di dalam Bab VI Pasal 30-34. Dalam Kompilasi Hukum Islam (KHI) diatur di dalam Bab XII Pasal 77-84 (Ahmad Rafiq, 2005). Pasal 30 UU Perkawinan menyatakan: Suami istri memikul kewajiban yang luhur untuk menegakkan rumah tangga yang menjadi sendi dasar dari susunan masyarakat" (R. Subekti dan R. Tjitrosudibio, 2004). Dalam rumusan redaksi yang berbeda, KHI Pasal 77 ayat (1) berbunyi: "Suami istri memikul kewajiban yang luhur untuk menegakkan rumah tangga yang sakinah, mawaddah, dan rahmah yang menjadi sendi dasar dan susunan masyarakat" (Tim redaksi Nuansa Aulia, 2015).

Kewajiban suami dapat dijelaskan antara lain memberi nafkah lahir dan batin kepada istrinya dengan ma'ruf (wajar), memberikan pendidikan yang terbaik kepada keturuannnya, menjadi imam dalam rumah tangganya, berbuat baik dan memberi perlindungan atas hak-hak istri dan anakanaknya, istimta' (memberi kenikmatan), dan kewajiban lain yang sudah diatur syariat dan aturan Negara. Adapun kewajiban istri diantaranya menaati suami dalam kebaikan, memelihara harta, martabat suami, memelihara diri dan harga dirinya, menyusui dan mendidik anak-anaknya, serta tidak keluar dari rumahnya kecuali dengan izin suami, mensyukuri nafkah yang diberikan suami, menyerahkan dirinya pada suami saat suami menginginkannya, tidak mengerjakan puasa (sunah), memasukkan tamu, tidak berpergian dan bersedekah tanpa izin suami, dan kewajiban lain yang diatur syariat dan hukum Negara (Gus Arifin, 2016).

Praktik khuruj yang dilakukan oleh jamaah tabligh harus memperhatikan hak dan kewajiban antara suami istri. Hal ini dikarenaka 
khuruj dapat saja (bahkan sangat lazim) dilakukan selama berhari-hari atau berminggu-minggu. Apabila tidak diperhatikan, akan mengganggu hak dan kewajiban masing-masing yang dapat berdampak pada ketidakharmonisan rumah tangga karena berkurangnya hak istri yang ditinggalkan (kurangnya nafkah dan perhatian) dan lalainya kewajiban yang semestinya ditunaikan seorang suami. Namun, apabila terdapat kesepakatan dan saling ridha antara keduanya, maka dalam pandangan maqashid al-syariah tidaklah menyalahi tujuan syariat karena tidak mendatangkan kemudharatan.

2. Efek khuruj terhadap Perceraian

Perceraian merupakan bagian dari cara menyelesaikan masalah. Oleh karena itu, perceraian mengandung beberapa hikmah. Pintu perceraian harus tetap terbuka, jika tertutup suami istri yang tidak ingin melanjutkan rumah tangganya disebabkan oleh berbagai hal yang prinsipil misalnya sesuatu yang membahayakan kedua belah pihak, misalnya suami gila, kasar, dan murtad, akan lebih tersiksa. Oleh karena itu perceraian hukumnya dapat menjadi wajib (Beni Ahmad Saebani, 2016).

Dalam hal pemberian nafaqah, dalam menjalankan praktik khuruj mungkin terjadi pada saat suami tidak dapat melaksanakan kewajibannya dan lain waktu dia mampu melakukan kewajiban itu. Dalam hal apakah kewajiban suami hanya berlaku pada waktu dia mampu saja dan hilang kewajibannya waktu-waktu ia tidak mampu atau dalam arti bersifat temporal; atau kewajibannya itu itu tetap ada, namun dalam keadaan tidak mampu kewajiban yang tidak dilaksanakannya itu merupakan utang baginya atau bersifat permanen. Hal ini menjadi pembicaraan di kalangan ulama (Amir Syarifuddin, 2014).

\section{Kemaslahatan dan kemudharatan khuruj}

Dua kewajiban antara pemenuhan kewajiban suami-isteri dengan kewajiban dakwah mempunyai kekuatan yang sama dengan berlandaskan kepada ayat Al-Qur'an bahkan dalam kondisi normal kedudukan dalam pemenuhan kewajiban suami-isteri dalam sebuah keluarga mempunyai kedudukan yang lebih utama dibandingkan dengan kewajiban berdakwah. Kenyataan yang terjadi di masyarakat kampung Paddhek kecamatan Pasean kabupaten Pamekasan pengikut kegiatan Jama ah Tabligh adalah tidak semua isteri dapat mengikuti pilihan dakwah suaminya bersama Jama ah Tabligh. Tidak semua isteri dengan suka rela menerima kondisi di mana dirinya harus berpisah dengan imam keluarganya dan ditinggalkan dalam waktu lama (Faiqoh Bahjah Lailatus Siyami, 2015).

Untuk kondisi tersebut Kompilasi Hukum Islam (KHI) mengatur dua hal. Pertama jika isteri tidak rela dengan keputusan suami yang bergabung dengan Jama'ah Tabligh, maka isteri boleh mengajukan gugatan kepada Pengadilan Agama sebagaimana disebutkan dalam KHI Pasal 77 ayat (5) bahwa 'jika suami atau isteri melalaikan kewajibannya masing-masing 
dapat mengajukan gugatan kepada Pengadilan Agama'. Kedua, jika ternyata isteri dengan suka rela menerima keputusan suami untuk pergi jauh berdakwah, KHI Pasal 80 ayat (6) mengatakan bahwa 'isteri dapat membebaskan suaminya dari kewajiban terhadap dirinya sebagaimana tersebut pada ayat (4) huruf a, b, dan c. Kewajiban tersebut berupa nafkah kiswah dan tempat kediaman bagi isteri, biaya rumah tangga, biaya perawatan dan biaya pengobatan bagi isteri dan anak serta biaya pendidikan bagi anak (Tim Redaksi Nuansa Aulia, 2015).

Dari penjelasan di atas setidaknya dapat diambil kesimpulan bahwa pengaruh khuruj pengikut Jamaah Tabligh terhadap percerain benar-benar terjadinya dikarenakan beberapa sebab diantaranya: Pemahaman wawasan agama yang kurang. Pengikut Jamaah Tabligh tidak memperhatikan aturan-aturan dalam khuruj, Seorang yang akan melakukan khuruj harus melakukan pengecekan. dalam hal ini harus harus diteliti kesiapannya yang berhubungan dengan niat, bekal, fisik dan keluarga yang akan ditinggal. Suami tidak melaksanakan kewajibannya memberikan nafkah dan meninggalkan istri tanpa pamitan untuk melaksanakan khuruj. Suami melakukan KDRT (karena terlalu sempit kepahaman terhadap agama). Hak istri dan anak terabaikan, sehingga menimbulkan keinginan untuk perceraian.

Sebagaimana dinyatakan Syatibi, bahwa umat Islam sepakat akan keberlakuan al-daruriyyat al-khamsah, atau disebut al-kulliyyat alkhamsah, yaitu pemeliharaan agama, jiwa, akal, keturunan, dan harta (AlSyatibi, 2003). Maka pemeliharaan agama (hifz al-Din) sebagai kaidah yang bersifat pasti, dianggap mencakup persoalan khuruj. Namun masalahnya, apakah kewajiban khuruj setiap anggota Jamaah Tabligh tergolong dalam daruriyyat?

Beranjak dari teorisasi Ibn 'Asyur, maka kewajiban khuruj setiap anggota Jamaah Tabligh sejalan dengan tujuan umum syariat, yaitu memelihara agama. Akan tetapi, kewajiban khuruj setiap anggota Jamaah Tabligh jika tidak melihat situasi dan kondisi keluarga akan menimbulkan mudarat untuk masa sekarang atau akan datang, oleh karena itu, kesiapan (pengecekkan keluarga harus diteliti kesiapannya yang berhubungan dengan niat, bekal, fisik dan keluarga yang akan ditinggal) menjadi utama dan wajib sebelum melakukan khuruj sehingga mudarat dapat ditolak. Jadi, jika anggota Jamaah Tabligh belum siap untuk melakukan khuruj maka kewajiban tersebut gugur. Sebagaimana diketahui, menolak mudarat adalah maslahat. Hal ini sahih, sebab khuruj merupakan al-maqasid alsyar'iyyat al-khassah yang sesuai dengan al-maqasid al-syar'iyyat al'ammah berdasar kriteria Ibn 'Asyur (Muhammad al-Tahir ibn 'Asyur, 2005). Ia menyatakan, bahwa yang ia maksud dengan 'kerusakan' adalah kerusakan yang menyebabkan kehidupan manusia menjadi seperti 


\section{binatang.}

Hal ini juga berhubungan dengan al-kulliyyat al-khamsah yang berupa pemeliharaan jiwa dan keturunan, sebab suami yang tidak memperhatikan istri dan anak akan turun derajatnya ke tingkat seperti binatang. Akibatnya, tatanan kehidupan sosial menjadi rusak, di mana istri terbebani mencari nafkah dan anak terlantar tidak sekolah. Menghindari yang mudharat lebih diutamakan.

\section{PENUTUP}

Praktik khuruj Jamaah Tabligh sesuai dengan tujuan umum syariat mempunyai kemaslahatan yaitu memelihara agama. Maka pemeliharaan agama (hifz al-Din) sebagai kaidah yang bersifat pasti, di dalam khuruj sejalan dengan syariat sehingga dapat disebut al-maqasid al-syariyyah. Akan tetapi, kewajiban khuruj setiap anggota Jamaah Tabligh haruslah melihat situasi dan kondisi kesiapan (pengecekkan keluarga harus diteliti kesiapannya yang berhubungan dengan niat, bekal, fisik dan keluarga yang akan ditinggal) menjadi utama dan wajib sebelum melakukan khuruj sehingga mudarat dapat ditolak untuk masa sekarang atau akan datang.

Untuk itu, problem keluarga yang ditinggalkan ketika khuruj haruslah benar-benar sudah diperhatikan kemaslahatan dan kemudharatannya. Jangan sampai atas nama dakwah membela agama meninggalkan kewajiban keluarga sehingga anak istri menjadi terlantarkan.

Saran dari peneliti, adanya penelitian lebih lanjut dengan menggunakan pendekatan Islam non doktrinal. 


\section{DAFTAR PUSTAKA}

A. Nasir, Sahilun.(2012). Pemikiran Kalam (Teologi Islam) Sejarah, Ajaran, dan Perkembangannya. PT. Rajagrafindo Persada: Jakarta.

Abu Hasan Ali al-Nadwi. (1990). Maulana Muhammad Ilyas. Terj. Masrokhan Ahmad, Yogyakarta: Ash Shaff.

Aditoni, Agus. (2011). "Pandangan Teologi Abu Hanifah". Disertasi--IAIN Sunan Ampel Surabaya, Surabaya.

Al-Syatibi. (2003). Al-Muwafaqat fi Usul al-Syari`ah, Jilid. I. Kairo: Maktabah al-Tawfiqiyyah.

al-Tahir ibn 'Asyur, Muhammad. (2005). Maqasid al-Syari'at al-Islamiyyah. Kairo: Dar al-Salam.

Arifin, Gus. (2016). Menikah untuk Bahagia Fiqih Nikah dan Kamasutra Islami. Jakarta: Kompas Gremedia.

Atho Mudzhar, M. (1998). Pendekatan Studi Islam dalam Teori dan Praktek. Yogyakarta: Pustaka Pelajar,.

Aziz, Abdul. (2004). "The Jamaah Tabligh Movement in Indonesia," Studia Islamika 11:3.

Bahjah Lailatus Siyami, Faiqoh. (2015). "Problem Praktik Khuruj bagi Anggota Jama ah Tabligh di Madura" al-Ihkam Vol. 10. No. 1 Juni.

Bukhari. (2015). "Penerimaaan dan Penolakan Pesan Dakwah dalam Interaksi Simbolik Da'i dan Mad'u pada Jamaah Tabligh di kota Padang",Miqot Vol. XXXIX No. 2 Juli-Desember.

Connolly, (2016). Peter Aneka Pendekatan Studi Agama, terj. Imam Khoiri. Yogyakarta: IRCiSoD.

Dalhari, Rawi. (2014). "Sejarah Masuk dan Perkembangan Jamaah Tabligh di Tamboro Magetan”. Skripsi-IAIN Sunan Ampel Surabaya, Surabaya.

Fahmi Muhammad 'Alwan, Fahmi. (1989). Al-Qiyam al-Daruriyyah wa Maqasid al-Tasyri' al-Islami. Kairo: al-Hay'ah al-Misriyyah.

Hasanah, Umdatul. (2014). "Keberadaan kelompok Jamaah Tabligh dan Reaksi Masyarakat (Perspektif Teori Penyebaran Informasi dan Pengaruh)" Indo-Islamika, Volume 4, Nomor 1, Januari-Juni.

http://m.nu.or.id

Junaedi, Didi. (2013). "Memahami Teks, Melahirkan Konteks: Menelisik Interpretasi Ideologis Jamaah Tabligh" , Journal of Qur'an and Hadith Studies - Vol. 2, No. 1.

Khoiriyah. (2013). Memahami Metodologi Studi Islam (Suatu Konsep tentang Seluk Beluk Pemahaman Ajaran Islam, Studi Islam dan Isu-isu Kontemporer dalam Studi Islam). Yogyakarta: Teras.

Muhyiddin, Asep. (2014). Kajian Dakwah Multiperspektif, Bandung : Rosda. Rafiq, Ahmad. (2015). Hukum Perdata Islam di Indonesia. Jakarta: Rajagrafindo Persada. 
R. Subekti dan R. Tjitrosudibio. (2004). Kitab Undang-undang Hukum Perdata. Jakarta: PT. Pradnya Paramita.

S. Thahir, Lukman. (2004). Studi Islam Interdisipliner Aplikasi Pendekatan Filsafat Sosiologi, dan Sejarah. Qirtas: Yogyakarta.

Saepuloh, Ujang. (2009). "Model Komunikasi Dakwah Jama'ah Tabligh", Jurnal Ilmu Dakwah, Vol. 4 No. 14 Juli-Desember.

Musolli, M. (2018). Maqasid Syariah: Kajian Teoritis dan Aplikatif Pada IsuIsu Kontemporer. AT-TURAS: Jurnal Studi Keislaman, 5(1), 60-81. https: / / doi.org/ 10.33650/at-turas.v5i1.324

Sirajuddin, A. (2016). MODEL PENEMUAN HUKUM DENGAN METODE MAQASHID SYARIAH SEBAGAI JIWA FLEKSIBELITAS HUKUM ISLAM. Istinbath: Jurnal Hukum, 13(1), 109-126.

Sugiyono, S. (2012). Memahami Penelitian Kualitatif. Bandung: Alfabeta.

Syarifuddin, Amir. (2014). Hukum Perkawinan Islam di Indonesia Antara Fiqh Munakahat dan Undang-undang Perkawinan. Kencana: Jakarta.

Tim redaksi Nuansa Aulia. (2015). Kompilasi Hukum Islam. Bandung: Nuansa Aulia.

Umar, Hamdan. (2016). "Komunitas Jamaah Tabligh di Kalangan Mahasiswa Surabaya (1990-2015)”. Skripsi-UIN Sunan Ampel Surabaya, Surabaya.

Wasman dkk. (2011). Hukum Perkawinan Islam di Indonesia Perbandingan Fiqh dan Hukum Positif. Teras: Yogyakarta.

Quraish Shihab, M. (2005). Tafsir Al-Mishbah, Vol. 2, Jakarta: Lentera Hati.

Muhammad Zakariyya Al-Kandahlawi Rah, Maulana. (2000). terj, A. Abdurrahman Ahmad. Himpunan fadhilah amal. Yogyakarta : AshShaff. 